\title{
Irrigation management based on reference evapotranspiration for pre-sprouted plantlets of sugarcane cultivars
}

\author{
Augusto Yukitaka Pessinatti Ohashi ${ }^{1}$ (D), Regina Célia de Matos Pires ${ }^{\star *}$ (D), Mauro Alexandre Xavier ${ }^{3}$ (D), \\ Dilermando Perecin ${ }^{4}$ iD, Laís Karina Silveira ${ }^{1}$ (D), Rômulo Henrique Petrỉ ${ }^{\text {(DD }}$ \\ 1. Instituto Agronômico - Programa de Pós-Graduação em Agricultura Tropical e Subtropical - Tecnologia da Produção \\ Agrícola - Campinas (SP), Brazil. \\ 2. Instituto Agronômico - Centro de Ecofisiologia e Biofísica - Campinas (SP), Brazil. \\ 3. Instituto Agronômico - Centro de Cana - Ribeirão Preto (SP), Brazil. \\ 4. Universidade Estadual Paulista “Júlio de Mesquita Filho" - Faculdade de Ciências Agrárias e Veterinárias - Departamento \\ de Ciências Exatas - Jaboticabal (SP), Brazil.
}

\begin{abstract}
The pre-sprouted sugarcane plantlets (PSP) system aims the production of healthy and vigorous plants in reduced time, reducing the number of stalks needed for planting. Irrigation is used in all PSP system stages and water management plays an important role. Stage 1 acclimation follows the budding stage and lasts for approximately 21 days. At this stage the plantlets are grown within an agricultural greenhouse to improve initial development. The objectives of this trial were: to identify the irrigation management which results in highest plantlet growth; to evaluate if responses to irrigation management depends on the cultivar; to evaluate water consumption and water use efficiency at early stage under PSP system; and to assess the water management effect on substrate water matrix potential and stomatal conductance in the cultivar IACSP95-5000. The experimental design was a split-plot randomized block design with four replications. Treatments applied in the plots were different irrigation depths based on daily reference evapotranspiration (ETo): 96, 80, 64 and $48 \%$, estimated by Penman-Monteith method. In the subplots, there were sugarcane cultivars IAC91-1099, IACSP95-5000 and IACSP97-4039. Irrigation management based on $80 \%$ ETo resulted in higher growth, dry mass accumulation and greater leaf area. Water use efficiency was not influenced by irrigation management. IAC91-1099 presented higher overall growth, leaf area and dry mass accumulation. Water consumption was cultivar-dependent in irrigation managements using 80 and $96 \%$ of ETo. Water use efficiency was higher in IAC911099 and lower in IACSP95-5000. Lower substrate water matrix potential reduced leaves stomatal conductance, impairing IACSP95-5000 plantlet growth.
\end{abstract}

Key words: evapotranspiration, greenhouse, water management, Saccharum spp., substrate, water use efficiency.
Received:

Jul. 29, 2019

Accepted:

Feb. 28, 2020

Section Editor:

Rafael Vasconcelos Ribeiro

${ }^{*}$ Corresponding author: rcmpires@iac.sp.gov.br

\section{INTRODUCTION}

The pre-sprouted sugarcane plantlets (PSP) sugarcane system aims to produce healthy and vigorous plantlets in short time, and also to decrease the number of stalks needed for planting. The plantlets are produced in small plastic tubes containing agricultural substrate and, after budding, the plantlets undergo two stages of acclimation under irrigation. Acclimation 1 is carried out inside greenhouse in order to allow the rapid plantlet growth (Landell et al. 2012). 
Water availability and adequate temperature are prerequisites for sugarcane budding, although studies have shown that either water deficit or water excess are detrimental to budding (Yang and Chen 1980). Moreira and Cardoso (1998) reported that not only budding was soil moisture-dependent, but also the budding curves were different among seasons. However, information about early sugarcane plantlet development is scarce. Then, criteria for water use efficiency are needed to obtain vigorous plantlets in short time under PSP system, in which irrigation is essential.

Inman-Bamber and Smith (2005) presented a review on water relations of sugarcane crop under field conditions and pointed out the need for studies in different sites, management and cultivars. Some studies noticed different responses to the water deficit among cultivars (Machado et al. 2009; Ribeiro et al. 2013; Boaretto et al. 2014). These results show the importance of studies considering variation in both water management and cultivars.

The PSP system, as a new production system, lacks information related to irrigation management and differential sensitivity of sugarcane cultivars. Libardi et al. (2019) determined the crop coefficient for three cultivars in PSP system, however there is still no data about how irrigation managements on PSP system affect plantlet growth and water use efficiency.

Herein, the hypotheses were: a) that there is an ideal water management based on evapotranspiration (ETo), which promotes both plantlet growth and water use efficiency; b) plantlet growth, water consumption and water use efficiency differ among cultivars; and c) irrigation management affects the substrate water matrix potential and consequently the growth of plantlets in the cultivar IACSP95-5000 due to the reduction of stomatal conductance. The objectives of this research were: to identify the irrigation management which results in highest plantlet growth, to evaluate if responses to irrigation management depends on the cultivar, to evaluate water consumption and water use efficiency at early stage under PSP system, and to assess the water management effect on substrate water matrix potential and stomatal conductance in 'IACSP95-5000'.

\section{MATERIAL AND METHODS}

\section{Growth conditions}

The protected environment for stage 1 acclimation was a greenhouse with $67.5 \mathrm{~m}$ length, $8.2 \mathrm{~m}$ width, $4.5 \mathrm{~m}$ right-foot, $6.5 \mathrm{~m}$ high in the roof center and east-west orientation. The greenhouse cover was a transparent polystyrene film Ginegar Polysack, with $150 \mu \mathrm{m}$ thickness, ultraviolet protection and 85\% transmission of photosynthetically active radiation. There was also a 50\% shading screen and the sides were closed with anti-aphid net.

\section{Experimental procedures}

Ministalks from the three sugarcane cultivars were obtained from upright stalks from sugarcane plants at eight months after planting. The plantlets production procedures were based on sugarcane PSP system developed by Landell et al. (2012). Thus, ministalks were obtained on September $14^{\text {th }}, 2015$ by removing old leaves from stalks, extracting $3.0 \mathrm{~cm}$ length ministalks and selecting those with visually undamaged buds. Chemical treatment was made using Azoxystrobin $(0.1 \%)$ to prevent fungi diseases. Ministalks were planted in a well-drained box filled with substrate. The boxes were put inside a temperature-controlled greenhouse $\left(34 \pm 2{ }^{\circ} \mathrm{C}\right)$ and high air humidity during seven days for the budding process (Landell et al. 2012). Thereafter, the budded ministalks were transplanted into $180 \mathrm{~cm}^{3}$ tubes, filled with the same substrate. The tubes were arranged in plastic trays $(0.47 \times 0.63 \mathrm{~m})$, each one with 63 tubes. The plastic trays were put on a $0.85 \mathrm{~m}$ height stand, hence at $0.65 \mathrm{~m}$ below the irrigation bar.

A commercial substrate based on mix of pinus bark and coconut fiber was used. Substrate dry density, aeration space and readily available water (RAW) was $0.23 \mathrm{~g} \cdot \mathrm{cm}^{-3}, 23.8 \%$ and $25.3 \%$, respectively. These data were obtained according to substrate physical analysis methodology (Zorzeto et al. 2014) and were adequate to plant propagation in cells and trays (Berjón et al. 2004; Zorzeto et al. 2014). The substrate water retention curve was done using tension table and Richards' pressure chamber with four replications (Fig. 1). 


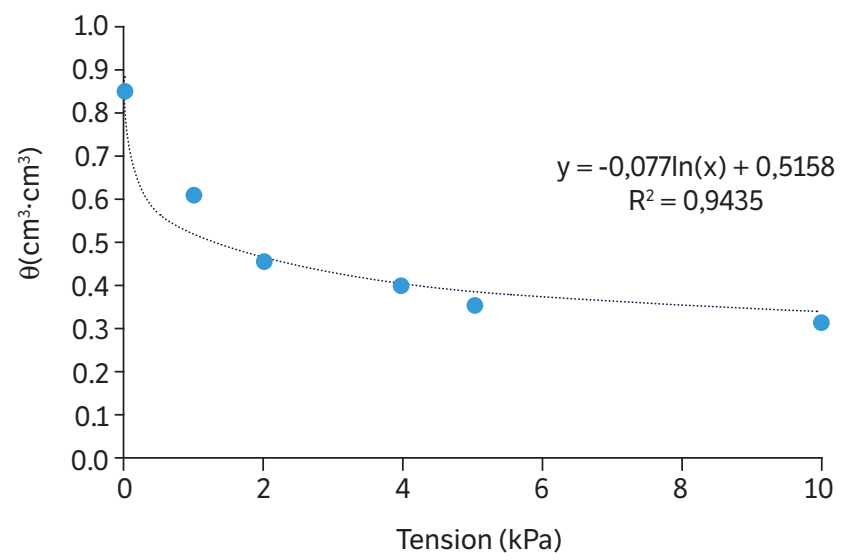

Figure 1. Water retention curve of the substrate used for pre-sprouted sugarcane plantlets procution

\section{Weather monitoring and irrigation}

The meteorological elements relative air humidity, air temperature, wind speed and net solar radiation were monitored inside and outside the greenhouse by automatic weather station (AWS). Evapotranspiration was estimated by the Penman-Monteith method (Allen et al. 1998) using outside AWS. GDD $\left({ }^{\circ} \mathrm{C}\right)$ was estimated according to Ometto (1981) using inside AWS data and following Eqs. 1 to 5:

$$
\text { If } \mathrm{Tm}>\mathrm{Tb} \text { and } \mathrm{TM}<\mathrm{TB} \text {, then: } \mathrm{GDD}=\left(\frac{\mathrm{TM}-\mathrm{Tm}}{2}\right)+(\mathrm{Tm}-\mathrm{Tb})
$$

or

$$
\text { if } \mathrm{Tm} \leq \mathrm{Tb}<\mathrm{TM} \text { and } \mathrm{TM}<\mathrm{TB} \text {, then: GDD }=\frac{(\mathrm{TM}-\mathrm{Tb})^{2}}{2(\mathrm{TM}-\mathrm{Tm})}
$$

or

$$
\text { if } \mathrm{TM}<\mathrm{Tb} \text { and } \mathrm{TM}<\mathrm{TB} \text { then: } \mathrm{GDD}=0
$$

or

$$
\text { if } \mathrm{Tm}>\mathrm{Tb} \text { and } \mathrm{TM}>\mathrm{TB} \text { then: } \mathrm{GDD}=(\mathrm{Tm}-\mathrm{Tb})+\frac{1}{2} \frac{(\mathrm{TM}-\mathrm{Tm})^{2}-(\mathrm{TM}-\mathrm{TB})^{2}}{2 \mathrm{TM}-\mathrm{Tm}}
$$

or

$$
\text { if } \mathrm{Tm}<\mathrm{Tb} \text { and } \mathrm{TM}>\mathrm{TB} \text { then: } \mathrm{GDD}=\frac{1}{2} \frac{(\mathrm{TM}-\mathrm{Tb})^{2}-(\mathrm{TM}-\mathrm{TB})^{2}}{2 \mathrm{TM}-\mathrm{Tm}}
$$

where: GDD: growing degree-day, ${ }^{\circ} \mathrm{C} \cdot \mathrm{d}^{-1} ; \mathrm{TM}$ : maximum daily temperature, ${ }^{\circ} \mathrm{C}$; Tm: minimum daily temperature, ${ }^{\circ} \mathrm{C}$; TB: superior basal sugarcane temperature, ${ }^{\circ} \mathrm{C}$; $\mathrm{Tb}$ : inferior basal sugarcane temperature, ${ }^{\circ} \mathrm{C}$; $\mathrm{TB}$ and $\mathrm{Tb}$ were 38 and $20^{\circ} \mathrm{C}$, respectively, according to Libardi et al. (2019) and considered inside greenhouse temperatures.

Minimum, maximum and average air temperature were, respectively, 19.5, 34.8 and $26.5^{\circ} \mathrm{C}$ (Fig. 2) inside greenhouse. Minimum temperature was slightly lower than inferior basal temperature $\left(20^{\circ} \mathrm{C}\right)$ in 15 days, and the lowest value was $16.8^{\circ} \mathrm{C}$ at 13 days after transplanting (DAT). Maximum temperature exceeded superior basal temperature $\left(38^{\circ} \mathrm{C}\right)$ in five days and the highest value was observed in the last day (22 DAT). Average air relative humidity was $57.1 \%$, varying from 35.5 to $80.3 \%$. Average net solar radiation was $3.7 \mathrm{MJ} \cdot \mathrm{m}^{-2} \cdot \mathrm{d}^{-1}$ and it ranged from $1.6 \mathrm{MJ} \mathrm{m}^{-2} \mathrm{~d}^{-1}$ in the coldest day to $6.5 \mathrm{MJ} \mathrm{m}^{-2} \cdot \mathrm{d}^{-1}$ in the hottest day. 
(a)

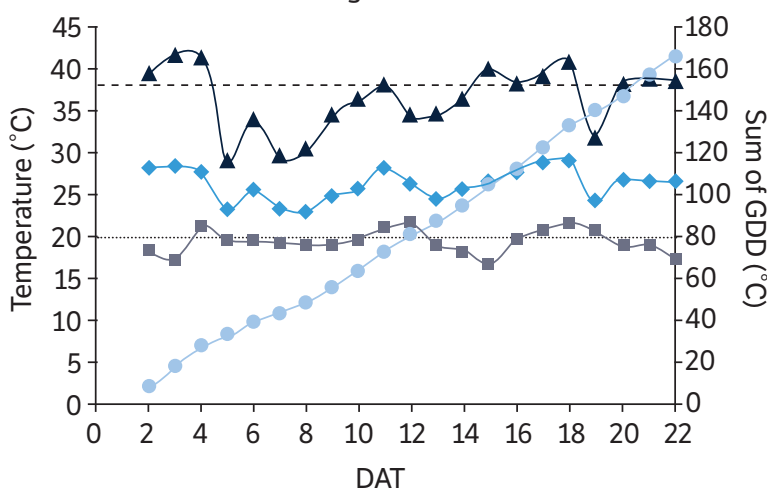

(b)

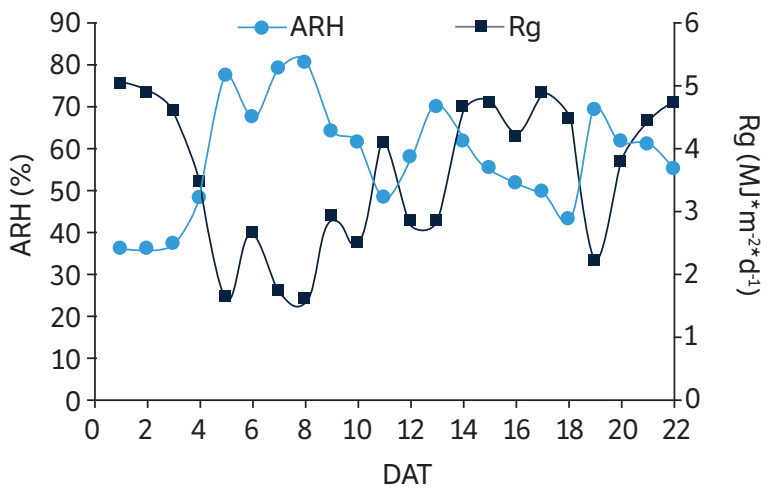

Figure 2. Maximum (TM), minimum (Tm), average (Tavg) daily temperature, maximum (TB) and minimum (Tb) sugarcane basal temperature and sum of growing degree-days (GDD) (a), air relative humidity (ARH) and global solar radiation (Rg) (b) inside the greenhouse during the experimental period.

Irrigation was performed using a mobile sprinkler irrigation bar at $1.5 \mathrm{~m}$ height from the ground. Its estimated Christiansen's uniformity coefficient was higher than $90 \%$ for all bar speed tested.

\section{Experimental design and treatments}

The experimental design was in split-plot randomized block with four replications. Each plot was formed by five plastic trays with 63 plantlets. Two trays in both plot borders were buffers and the three internal trays formed each one a subplot. There was also a two-trays-wide space between the border of a plot and the next one border to enable the irrigation bar speed to change for irrigation depth variation according to each irrigation treatment.

The primary treatments (plots) were 120, 100, 80 and 60\% of ETo. However, as the PSP system takes place inside a greenhouse, which reduces both the radiation factor and the aerodynamic factor (Fernandes et al. 2003), the correction factor of $80 \%$ was applied in the aforementioned values (Braga and Klar 2000). Thus, the primary treatments applied were 96, 80, 64 and 48\% of mean three-previous-day ETo. Irrigation was done three times a day considering the irrigation depth in each treatment, by changing the irrigation bar speed.

The secondary treatments (subplots) were the plastic trays containing one cultivar each: IAC91-1099, IACSP95-5000 and IACSP97-4039. 'IACSP95-5000' is recommended for fertile soils and some studies reported results that suggest it is susceptible to water deficit when compared to others (Machado et al. 2009; Ribeiro et al. 2013; Boaretto et al. 2014), although Marchiori et al. (2017) verified that it has some resistance to mild water stress. 'IAC91-1099' has higher plasticity than 'IACSP95-5000' concerning crop environment and it is suited for planting in regions with higher water deficit compared to 'IACSP95-5000' (Landell et al. 2007). 'IACSP97-4039' is the most indicated to restrictive environments with poor soils and water deficit (Gomes 2013). Marchiori et al. (2017) verified that morphological and physiological traits are both cultivarand drought-dependent. Thus, it is important to understand cultivar response to different water deficit intensities.

\section{Evaluations}

Plantlets height and diameter evaluations were performed at 23 DAT. Six plantlets from the center of the tray were measured and the mean value was considered as the height and diameter replication value in each subplot. At the end of the experiment, 15 plantlets from the center of each tray were sampled. Shoot dry mass (SDM) and root dry mass (RDM) were evaluated by drying separately 15 shoots and roots at $65^{\circ} \mathrm{C}$ until constant weight. The mean value of 15 shoots and roots was considered as the SDM and RDM replication value in each subplot. Total dry mass (TDM) was calculated by the sum of SDM and RDM. 
Plantlet leaf area (PLA) was estimated using five plantlets per subplot, randomly selected among the 15 sampled for the dry mass analysis. Leaves were separated and scanned on LI-3100 benchtop scanner (LI-COR Inc., Lincoln, NE - USA). The mean value of the five plantlets was considered as the PLA value of each subplot replicate.

Leaf area index (LAI) was obtained by Eq. 6:

$$
L A I=\frac{P L A \times 63}{0.296}
$$

where: LAI: leaf area index $\left(\mathrm{cm}^{2} \cdot \mathrm{cm}^{-2}\right)$; LA: plantlet leaf area $\left(\mathrm{cm}^{2}\right) ; 63$ is the number of plantlets in the subplot; 0.296 is the subplot area $\left(\mathrm{cm}^{2}\right)$;

A drainage collector was installed below each subplot in order to measure water loss after irrigation. Water consumption was calculated by Eq. 7:

$$
\text { Water consumption }(m m)=A D-P D
$$

where: AD: applied irrigation depth (mm); PD: percolated depth (mm).

The percolated depth was measured $30 \mathrm{~min}$ after irrigation and water use efficiency (WUE) was calculated by Eq. 8:

$$
\text { WUE }=\frac{T D M \times 63}{\text { Water cons. }}
$$

where: WUE: water use efficiency $\left(\mathrm{g} \cdot \mathrm{mm}^{-1}\right)$; TDM: plantlet total dry mass $(\mathrm{g}) ; 63$ is the number of plantlets in the subplot; Water cons.: subplot water consumption $(\mathrm{mm})$;

Stomatal conductance $\left(\mathrm{g}_{\mathrm{s}}\right)$ was measured at 14 DAT during the following intervals: between 8:00 and 8:30 AM, between 2:30 and 3:00 PM and between 4:00 and 4:30 PM. The dynamic equilibrium porometer model AP4 (Delta-T Devices Ltd., Cambridge, UK) was used, with four replications per treatment (irrigation management) in 'IACSP95-5000'. The measurements were taken only in this cultivar due to the time interval in order to collect all replications in all four irrigation managements. It was stablished $30 \mathrm{~min}$ as maximum time interval between first and last measurement, hence preventing environmental effect influence on $\mathrm{g}_{\mathrm{s}}$. 'IACSP95-5000' was chosen because it has been used in previous studies.

Substrate water matrix potential (SWP) was monitored by MRI gas tensiometers (Hidrosense, Jundiaí, SP, Brazil). These tensiometers use pressurized gas inside ceramic capsule pores, which allows the monitoring of the substrate water matrix potential. The sensors were installed at middle height of plastic tube in 'IACSP95-5000' plots in different irrigation depth with six capsules per treatment. Due to limited number of sensors, the authors of this study chose to install it in 'IACSP95-5000' for the same reason aforementioned, added to the fact of obtaining these data in the same cultivar in which the stomatal resistance was measured, making it possible to know the relationship between these important factors.

\section{Statistical analysis}

The data were statistically analyzed using the software $\mathrm{R}$ (R Core Team 2018). The analysis of residues normality was performed by Shapiro-Wilk test. Analysis of variance (ANOVA) was done applying the F test and Tukey's test $(\mathrm{p}<0.05)$ to cultivars and irrigation management. The package used in the R software was the "ExpDes" (Ferreira et al. 2014). 


\section{RESULTS AND DISCUSSION}

\section{Substrate water matrix potential}

Irrigation managements resulted in different substrate matrix potential values (Fig. 3), which remained higher in the treatments with 80 and $96 \%$ ETo than the others.

The SWP was less negative in the treatment with $64 \%$ ETo than that verified in $48 \%$ ETo, in which SWP was around $-4 \mathrm{kPa}$ up to $16 \mathrm{DAT}$ and thereafter reached values as negative as $-10 \mathrm{kPa}$. Considering substrate water retention curve (Fig. 1), it was observed that in the three last days there was no RAW to plantlets submitted to $48 \%$ ETo, as its SWP was below $-5 \mathrm{kPa}$ (Fig. 3), according to Zorzeto et al. (2014). A similar but less pronounced trend was observed in $64 \%$ of ETo. Thus, it can be argued that irrigation depths were not enough to balance water demand by 'IACSP95-5000' plantlets in 48 and $64 \%$ ETo, especially in the former.

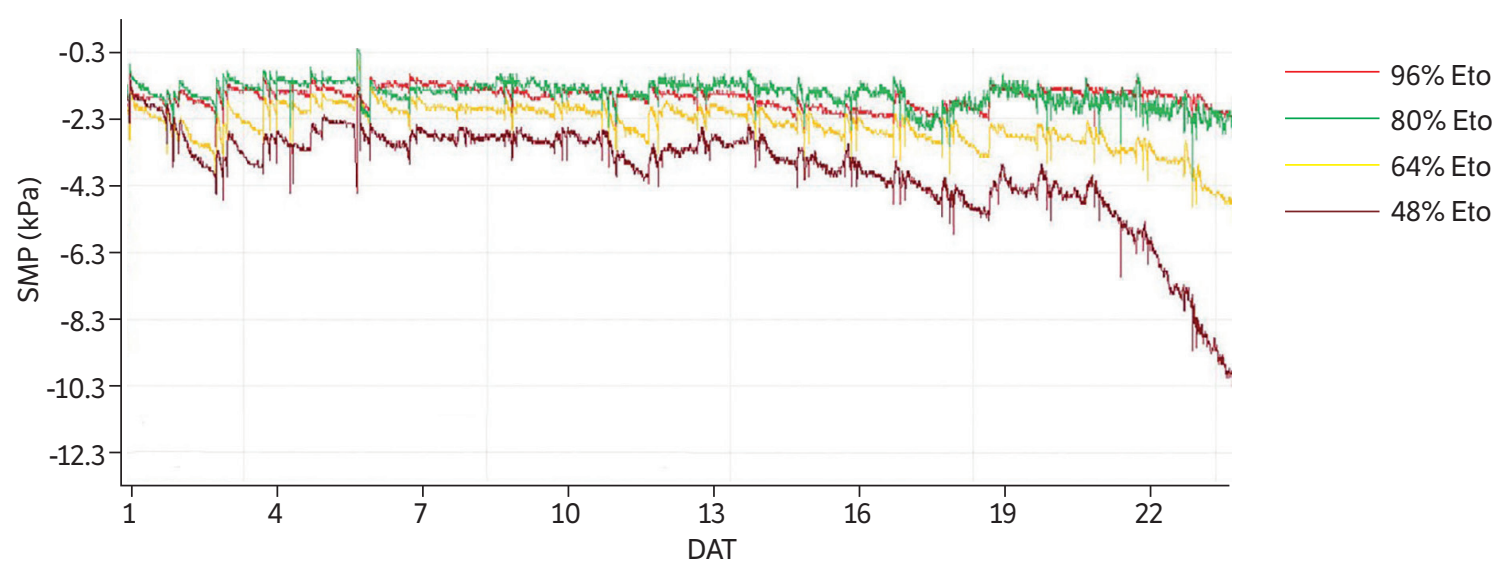

Figure 3. Substrate water potential (SWP) in each irrigation treatments (percentages of reference evapotranspiration - ETo) during 22 experimental days in IACSP95-5000 cultivar. DAT = days after transplanting.

\section{Stomatal conductance}

Irrigation managements had effect on IACSP $95-5000 \mathrm{~g}_{\mathrm{s}}$, as observed at 14 DAT (Fig. 4). Plantlets submitted to $48 \%$ ETo irrigation management had lower $\mathrm{g}_{\mathrm{s}}$ values than $80 \%$ ETo at two out of three times when $\mathrm{g}_{\mathrm{s}}$ was measured and in all three compared to $96 \%$ ETo (Fig. 4). The 64\% ETo treatment had similar $g_{s}$ values to $80 \%$ ETo at morning, although its $g_{s}$ decreased as low as $48 \%$ ETo during afternoon.

The $\mathrm{g}_{\mathrm{s}}$ data show that applying $80 \%$ ETo had similar effect to $96 \%$ ETo with saving $20 \%$ of irrigation depth. When using $48 \% \mathrm{ETo}, \mathrm{g}_{\mathrm{s}}$ was significantly reduced even at early morning, which indicates that plantlets could not restore its water status during night (Fig. 4). The 64\% ETo management could restore its water status at morning, as it had similar $\mathrm{g}_{\mathrm{s}}$ to $80 \%$ ETo, however during day it could not maintain $\mathrm{g}_{\mathrm{s}}$ as high as observed 80 and $96 \%$ ETo.

The SWP at 14 DAT corroborates the $g_{s}$ values (Fig. 4b), as $48 \%$ of ETo had lower SWP values than the others, hence indicating that water was strongly retained, which reduced plantlets $\mathrm{g}_{\mathrm{s}}$.

Although SWP values were apparently similar between 64 and $96 \%$ of ETo, in the two first measurements there was less than $50 \%$ of RAW in the $64 \%$ of ETo (Fig. 4c), whereas the $96 \%$ ETo still had around $60 \%$ of RAW, which did not restricted $g_{s}$.

In the measurement at 4:00 PM, after third and last daily irrigation, substrate RAW was increased in 64\% of ETo treatment to around 55\% (Fig. 4c). However, this RAW increase did not improved $\mathrm{g}_{\mathrm{s}}$, showing that plantlets in this treatment still did not have recovered $g_{s}$ up to the values observed at 8:00 (Fig. 4a). 
(a)

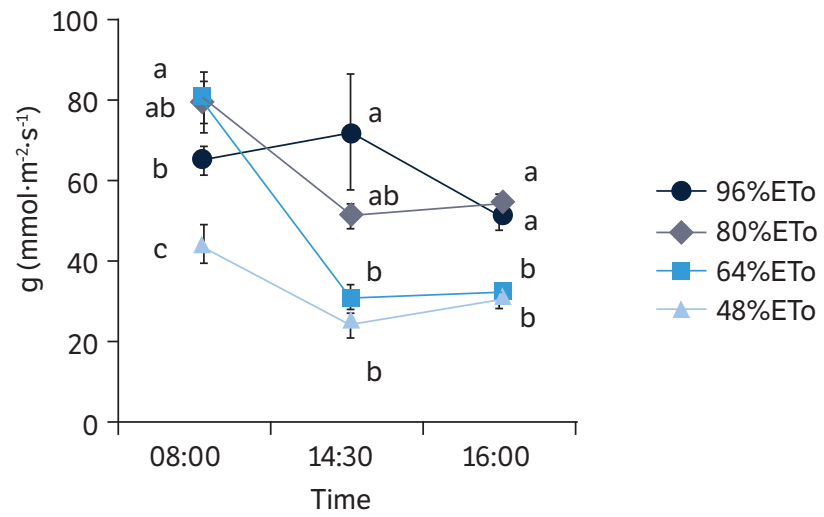

(b)

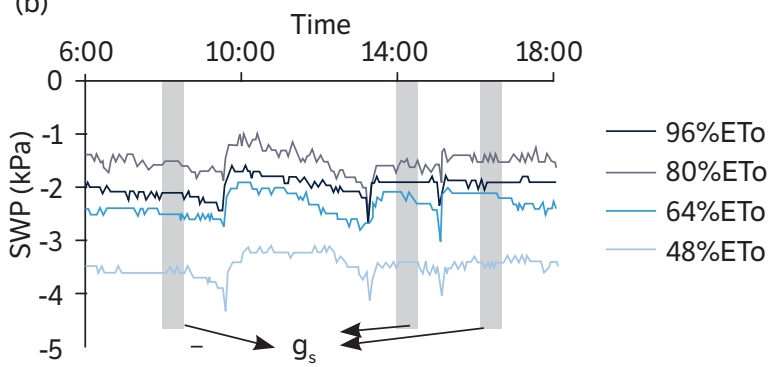

(c)

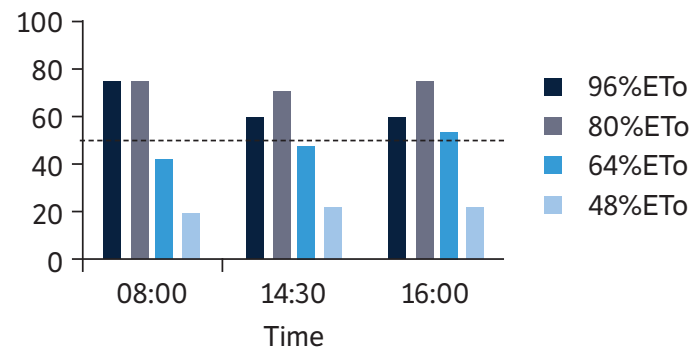

Figure 4. Plantlet stomatal conductance $\left(\mathrm{g}_{\mathrm{s}}\right)(\mathrm{a})$, substrate water matrix potential (SWP) (b) and readily available water (RAW) (c) in irrigation managements based on percentage of reference evapotranspiration (ETo) for cultivar IACSP95-5000 in three times during 14th day after transplanting. Bars represent mean error. Grey bars in (b) represents the time interval in which $\mathrm{g}_{\mathrm{s}}$ was assessed at 14 days after transplanting.

Silveira et al. (2017) evaluated sugarcane plantlets submitted to cultivation in nutrient solution and under controlled conditions for 21 days. They obtained values of $g_{s}$ between 100 and $150 \mathrm{mmol} \cdot \mathrm{m}^{-2} \cdot \mathrm{s}^{-1}$ for cultivar IACSP94-2094 between 11:00 AM and 1:00 PM, which may indicate that during plantlet stage the $\mathrm{g}_{\mathrm{s}}$ is lower than in field cultivation conditions. In fact, the observed values of $g_{s}$ by Silveira et al. (2017) are slightly higher to those observed in this experiment at 2:30 PM in treatments with higher percentages of ETo. This difference could be due to plantlets used by Silveira et al. (2017) were around 30 days older than the plantlets used in this study. However, the average $\mathrm{g}_{\mathrm{s}}$ in irrigation management with $48 \%$ of the ETo was only $9.7 \mathrm{mmol} \cdot \mathrm{m}^{-2} \cdot \mathrm{s}^{-1}$, (Fig. 4) which shows the effect of water stress on the plantlets.

\section{Water consumption}

Irrigation managements had effect on plantlets water consumption and this effect was cultivar-dependent. Daily irrigation depth in 96 and 80\% ETo was always higher than daily plantlet water consumption (Fig. 5a and b), hence there was no water deficit. On the other hand, daily irrigation depth and daily plantlet water consumption were equivalent in $48 \%$ ETo (Fig. 5d), which means that plantlet under this treatment could be under water deficit. In fact, water consumption, regardless cultivar, was lower in $48 \%$ ETo (Table 1). However, differences among cultivars water consumption in the other water managements were observed. Daily irrigation depth and daily plantlet water consumption in 64\% ETo were close, especially after 7 DAT (Fig. 5c), hence resulting in water deficit in 'IAC91-1099' and 'IACSP97-4039' due to the fact that their water consumption was lower than observed in 80\% ETo (Table 1). 'IACSP95-5000', however, had the same water consumption than 80 and $96 \%$ ETo, which implies that $64 \%$ ETo did not resulted in overall water deficit for this cultivar. Nevertheless, 'IACSP95-5000' experienced water deficit during experimental period, as the observed $\mathrm{g}_{\mathrm{s}}$ reduction under 64\% ETo at 14 DAT compared to $80 \%$ ETo (Fig. 4).

Average daily water consumption under 80\% ETo ranged from 2.9 ('IACSP95-5000') to $3.2 \mathrm{~mm}$ ('IAC91-1099'). Under 96\% ETo, mean daily consumption was $2.8 \mathrm{~mm}$ in 'IACSP95-5000', $3.0 \mathrm{~mm}$ in 'IACSP97-4039' and $3.3 \mathrm{~mm}$ in 'IAC91-1099'. 
(a)

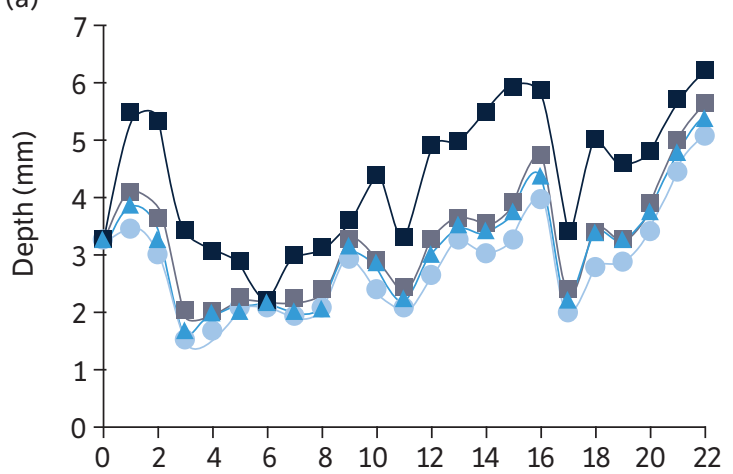

(c)

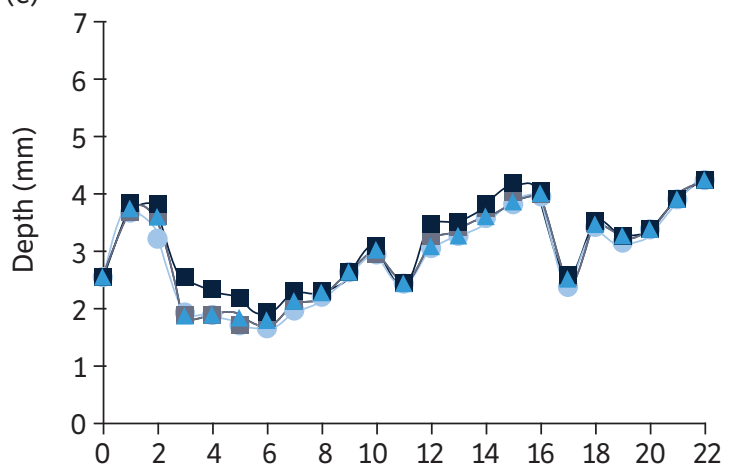

(b)

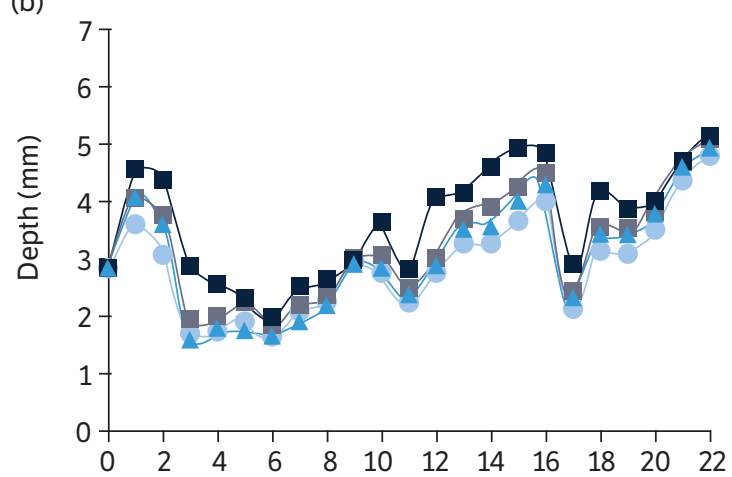

(d)

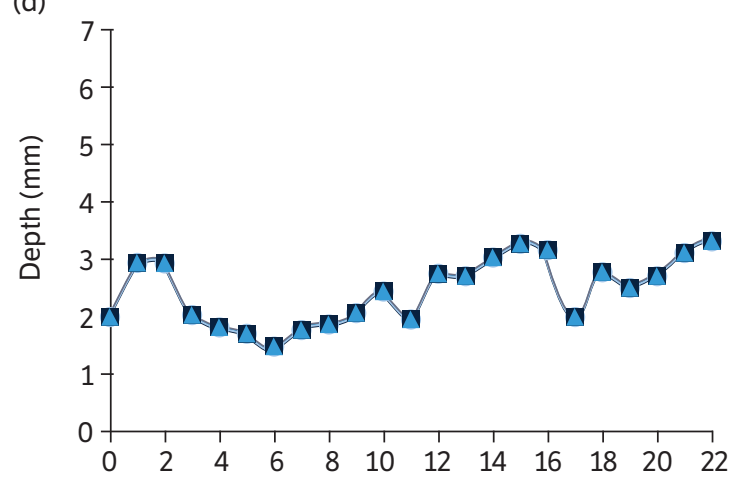

Figure 5. Irrigation depth applied (DA) and daily plantlet water consumption (DC) in irrigation management based on $96 \%$ (a), $80 \%$ (b), $64 \%$ (c) and 48\% (d) of ETo for cultivars IAC91-1099, IACSP95-5000 and IAC97-4039 during experimental days. DAT = days after transplanting.

Table 1. Total plantlet water consumption considering irrigation managements and cultivars. Means followed by the same capital letter in the row and lowercase in the column do not differentiate according to the Tukey's test $(p<0.05)$.

\begin{tabular}{|c|c|c|c|}
\hline \%ETo & ‘IACSP95-5000’ (mm) & 'IACSP97-4039’ (mm) & 'IAC91-1099' (mm) \\
\hline 96 & $65.3 \mathrm{Ca}$ & $69.8 \mathrm{Ba}$ & $74.8 \mathrm{Aa}$ \\
\hline 80 & $66.0 \mathrm{Ba}$ & $70.3 \mathrm{Aa}$ & $73.3 \mathrm{Aa}$ \\
\hline 64 & $60.5 \mathrm{Aa}$ & $62.3 \mathrm{Ab}$ & $62.6 \mathrm{Ab}$ \\
\hline 48 & $49.6 \mathrm{Ab}$ & $49.7 \mathrm{Ac}$ & $49.8 \mathrm{Ac}$ \\
\hline F (\%ETo) & & $47.05^{\star \star}$ & \\
\hline F (Cultivar) & & 17.50 ** & \\
\hline F (\%ETo × Cultivar) & & 3.70 * & \\
\hline CV\% (\%ETo) & & 6.65 & \\
\hline CV\% (Cultivar) & & 3.15 & \\
\hline
\end{tabular}

${ }^{\star}$ significant value $(p<0.05),{ }^{\star *}$ significant value $(p<0.01)$

Water consumption data for PSP system are scarce in literature. Libardi et al. (2019) measured crop evapotranspiration using weighing lysimeters and the mean daily value was approximately $3.9 \mathrm{~mm}$ for 'CTC9005HP', 'RB966928' and 'SP87365'. This slightly higher value of water consumption reported by Libardi et al. (2019) may be justified by higher temperatures and different cultivars. 


\section{Plantlet growth and water use efficiency}

There was no significant interaction between irrigation management and cultivar, but both affected plantlet height, diameter, SDM, TDM and PLA. Irrigation with 48\% ETo resulted in lower height, diameter, SDM, TDM and PLA. Among the cultivars, there was a different response for height and diameter. Although presenting lower height, 'IACSP95-5000' had larger diameter when compared to 'IACSP97-4039' (Table 2). 'IAC91-1099' presented higher plantlet height and diameter, matching the height of 'IACSP97-4039' and the diameter of 'IACSP95-5000'. 'IAC91-1099' presented higher PLA, SDM and TDM than the other cultivars, while 'IAC91-1099' and 'IACSP97-4039' had higher RDM than 'IACSP95-5000'. Data concerning PSP growth are scarce, hence there are no other published studies that could be used to compare the results of this study. Nevertheless, this lack of studies highlights this data novelty about PSP growth and how it was affected by irrigation management.

Plantlet leaf area had slightly different response according to irrigation management as it was the only characteristic in which 64\% ETo treatment had lower values than 80 and 96\% (Table 2). Libardi et al. (2019) evaluated LAI of plantlets of three cultivars and obtained values between 2.4 and 3.3 at approximately 20 DAT. Treatment with 64\% of ETo resulted in mean LAI of 2.4 (Table 2), which was similar to that obtained by Libardi et al. (2019) to the cultivar CTC9005HP. However, it should be noted that this cultivar was conducted without water restriction by Libardi et al. (2019), which differs from this study when applying only $64 \%$ of ETo. The treatments in which 80 and $96 \%$ of ETo were applied presented LAI of 3.0 and 2.7, respectively. These data indicate that some value difference can be also associated to cultivars and show the necessity to consider these differences.

The water deficit effect on plantlet height, diameter and TDM presented herein, as well as IACSP95-5000 $\mathrm{g}_{\mathrm{s}}$ data corroborate literature results observed in other plant species (van den Driessche 1991; Bañon et al. 2006; Díaz-Lópes et al. 2012). These results evidenced that water stress decreased plantlets stomatal conductance, growth and dry mass accumulation even in a short time period. However, despite the difference observed in water consumption and TDM (Table 2), there was no difference in WUE regarding irrigation management, which indicates that plantlets growth is water-regulated and WUE was maintained under water deficit due to morphological, such as reducing LA, and physiological, such as stomatal conductance, changes in sugarcane plantlets when submitted to water deficit. This water conservation strategy was also observed by Díaz-López et al. (2012) to Jatropha curcas L. seedlings and it was similar to that reported by van den Driessche (1991) to tree species seedlings and by Bañon et al (2006) to Nerium oleander L.

Table 2. Plantlet height $(H)$, diameter $(\varnothing)$ leaf area (LA), leaf area index (LAI), leaf area index (LAI) shoot dry mass (SDM), root dry mass (RDM), plantlet dry mass (TDM) and water use efficiency (WUE) for irrigation managements and cultivars.

\begin{tabular}{|c|c|c|c|c|c|c|c|c|}
\hline \multirow{2}{*}{ \%ETo } & $\mathbf{H}$ & $\varnothing$ & LA & LAI & SDM & RDM & TDM & WUE \\
\hline & $\mathrm{cm}$ & $\mathrm{cm}$ & $\mathrm{cm}^{2}$ & $\mathrm{~cm}^{2} \cdot \mathrm{cm}^{-2}$ & g & g & g & $\mathrm{g} \mathrm{mm}^{-1}$ \\
\hline 96 & $12.4 \mathrm{a}$ & $0.69 a$ & $130.5 \mathrm{a}$ & 3.3 & $1.012 \mathrm{a}$ & $0.137 a$ & $1.15 a$ & $1.07 \mathrm{a}$ \\
\hline 80 & $12.6 \mathrm{a}$ & $0.70 \mathrm{a}$ & $143.6 \mathrm{a}$ & 3.6 & $1.059 a$ & $0.136 a$ & $1.19 \mathrm{a}$ & $1.03 \mathrm{a}$ \\
\hline 64 & $11.6 \mathrm{a}$ & $0.64 a b$ & $112.2 \mathrm{~b}$ & 2.8 & $0.925 a$ & $0.139 a$ & $1.06 \mathrm{a}$ & $1.09 \mathrm{a}$ \\
\hline 48 & $9.2 \mathrm{~b}$ & $0.57 b$ & $85.2 \mathrm{c}$ & 2.1 & $0.728 b$ & $0.133 a$ & $0.86 \mathrm{~b}$ & $1.09 \mathrm{a}$ \\
\hline \multicolumn{9}{|c|}{ Cultivar } \\
\hline IAC91-1099 & $12.4 \mathrm{a}$ & $0.68 a$ & 136.1 a & 3,4 & $1.040 \mathrm{a}$ & $0.155 a$ & $1.20 \mathrm{a}$ & $1.16 \mathrm{a}$ \\
\hline IACSP97-4039 & $11.6 \mathrm{a}$ & $0.60 \mathrm{~b}$ & $116.4 \mathrm{~b}$ & 2,9 & $0.865 b$ & $0.140 \mathrm{a}$ & $1.00 \mathrm{~b}$ & $1.05 a b$ \\
\hline IACSP95-5000 & $10.3 \mathrm{~b}$ & $0.68 a$ & $101.0 \mathrm{~b}$ & 2,5 & $0.888 \mathrm{~b}$ & $0.113 \mathrm{~b}$ & $1.00 \mathrm{~b}$ & $1.00 \mathrm{~b}$ \\
\hline F (\%ETo) & $33.91^{\star \star}$ & $8.22^{\star}$ & $40.3^{\star \star}$ & - & $19.15^{\star \star}$ & $0.09 \mathrm{~ns}$ & $13.53^{\star \star}$ & $0.52 \mathrm{~ns}$ \\
\hline F (Cultivar) & $14.01^{\star \star}$ & $7.92^{\star \star}$ & $14.1^{\star \star}$ & - & $10.71^{\star \star}$ & $15.71^{\star \star}$ & $10.85^{\star \star}$ & $5.73^{\star \star}$ \\
\hline F $(\%$ ETo $\times$ Cultivar $)$ & $1.48 \mathrm{~ns}$ & $1.24 \mathrm{~ns}$ & $1.3 \mathrm{~ns}$ & - & $1.85 \mathrm{~ns}$ & $1.84 \mathrm{~ns}$ & $1.70 \mathrm{~ns}$ & $0.96 \mathrm{~ns}$ \\
\hline CV\% (\%ETo) & 7.16 & 9.32 & 11.7 & - & 12.43 & 20.84 & 13.03 & 12.03 \\
\hline CV\% (Cultivar) & 8.72 & 8.70 & 15.9 & - & 12.53 & 15.52 & 12.64 & 12.57 \\
\hline
\end{tabular}

${ }^{*}$ significant value $(p<0.05)$, ${ }^{\star *}$ significant value $(p<0.01)$. 
Considering that the water use efficiency is estimated by the correlation between total dry matter and water consumption, it should be noted that there was interaction between irrigation management and cultivars factors for water consumption (Table 1). On the other hand, this interaction did not occur for total dry mass. According to Table 2, there was difference between WUE and TDM between 'IACSP95-5000' and 'IAC91-1099'. It is noticed that in treatments where there was no water deficit, 'IAC91-1099' showed significantly higher water consumption than 'IACSP95-5000'. However, TDM of 'IAC91-1099' was also higher. Thus, despite the higher water consumption of this cultivar, it was more efficient to use water for dry mass production, hence presenting higher WUE.

\section{CONCLUSIONS}

Irrigation management based on $80 \%$ of the reference evapotranspiration resulted in higher growth, dry mass accumulation and greater leaf area. Water use efficiency was not influenced by irrigation management.

'IAC91-1099' presented higher overall growth, leaf area and dry mass accumulation. Water consumption was cultivardependent in irrigation managements using 80 and $96 \%$ of the reference evapotranspiration. Water use efficiency was higher in 'IAC91-1099' and lower in 'IACSP95-5000'.

Lower substrate water matrix potential reduced leaves stomatal conductance, impairing 'IACSP95-5000' plantlet growth.

\section{FUNDING}

Coordenação de Aperfeiçoamento de Pessoal de Nível Superior

[https://doi.org/10.13039/501100002322]

Grant \#1527468

\section{ACKNOWLEDGMENT}

To Hidrosense for kindly providing us the MRI gas tensiometers.

\section{AUTHOR'S CONTRIBUTION}

Conceptualization, Ohashi, A. Y. P., Pires, R. C. M., Perecin, D. and Xavier, M. A.; Data curation, Ohashi, A. Y. P., Pires, R. C. M., Petri, R. H.; Formal analysis, Ohashi, A. Y. P., Pires, R. C. M., Perecin, D., Silveira, L. K.; Methodology, Ohashi, A. Y. P., Pires, R. C. M., Perecin, D., Petri, R. H. and Xavier, M. A.; Project administration, Ohashi, A. Y. P., Pires, R. C. M., Xavier, M. A., Petri, R. H.; Investigation, Ohashi, A. Y. P., Pires, R. C. M., Silveira, L. K. and Xavier, M. A.; Writing Original Draft, Ohashi, A. Y. P., Pires, R. C. M., and Silveira, L. K.; Writing - Review and Editing, Ohashi, A. Y. P., Pires, R. C. M., and Silveira, L. K.; Funding Acquisition, Pires, R. C. M. and Xavier, M. A.; Resources, Pires, R. C. M., Xavier, M. A. and Petri, R. H.; Supervision, Pires. R. C. M. and Xavier, M. A.

\section{REFERENCES}

Allen, R. G., Pereira, L. S., Raes, D. and Smith, M. (1998). Crop evapotranspiration-Guidelines for computing crop water requirementsFAO Irrigation and drainage paper 56. Rome: FAO. 
Bañon, S., Ochoa, J., Franco, J. A., Alarcón, J. J. and Sánchez-Blanco, M. J. (2006). Hardening of oleander seedlings by deficit irrigation and low air humidity. Environmental and Experimental Botany, 56, 36-43. https://doi.org/10.1016/j.envexpbot.2004.12.004

Berjón, M. A., Murray, P. N. and Benedito, C. C. (2004). Los sustratos em los cultivos sin suelo. In M. U. Gavilán, (Ed.). Tratado de cultivo sin suelo (p. 113-159). Madrid: Mundi-Prensa.

Boaretto, L. F., Carvalho, G., Borgo, L., Creste, S., Landell, M. G. A., Mazzafera, P. and Azevedo, R. A. (2014). Water stress reveals differential antioxidant responses of tolerant and non-tolerant sugarcane genotypes. Plant Physiology and Biochemistry, 74, 165-175. https://doi. org/10.1016/j.plaphy.2013.11.016

Braga, M. B. and Klar, A. E. (2000). Evaporação e evapotranspiração de referência em campo e estufa orientadas nos sentidos nortesul e leste-oeste. Irriga, 5, 188-193. https://doi.org/10.15809/irriga.2000v5n3p188.

Díaz-López, L., Gimeno, V., Simón, I., Martínez, V., Rodríguez-Ortega, W. M. and García-Sánchez, F. (2012). Jatropha curcas seedlings show a water conservation strategy under drought conditions based on decreasing leaf growth and stomatal conductance. Agricultural Water Management, 105, 48-56. https://doi.org/10.1016/j.agwat.2012.01.001

Fernandes, C., Corá, J. E. and Araújo, J. A. C. (2003). Reference evapotranspiration estimation inside greenhouses. Scientia Agricola, 60, 591-594. https://doi.org/10.1590/S0103-90162003000300027

Ferreira, E. B., Cavalcanti, P. P. and Nogueira, D. A. (2014). ExpDes: An R package for ANOVA and experimental designs. Applied Mathematics, 5, 2952-2958. https://doi.org/10.4236/am.2014.519280

Inman-Bamber, N. G. and Smith, D. M. (2005). Water relations in sugarcane and response to water deficits. Field crops research, 92, 185-202. https://doi.org/10.1016/j.fcr.2005.01.023

Gomes, C. (2013). [IAC] Instituto Agronômico. Novas cultivares de cana IAC têm alto teor de sacarose e mantêm alta produtividade durante toda a safra. [IAC] Instituto Agronômico. [Accessed Mar. 13, 2020]. Available at: http://www.iac.sp.gov.br/noticiasdetalhes.php?id=894

Landell, M. G. A., Campana, M. P., Figueiredo, P., Xavier, M. A., Vasconcelos, A. C. M., Bidoia, M. A., Silva, D. N., Anjos, I. A., Prado, H., Pinto, L. R., Souza, S. A. C. D., Scarpari, M. S., Rosa Junior, V. E., Jr., Dinardo-Miranda, L. L., Azania, C. A. M., Perecin, D., Rossetto, R., Silva, M. A., Martins, A. L. M., Gallo, P., Kanthack, R. A. D., Cavichioli, J. C., Veiga Filho, A. A., Mendonça, J. R., Dias, F. L. F. and Garcia, J. C. (2007). Boletim técnico IAC, 201: Variedades de cana-de-açúcar para o Centro-Sul do Brasil: 16a Liberação do Programa Cana IAC (1959-2007). Ribeirão Preto: Instituto Agronômico de Campinas.

Landell, M. D. A., Campana, M. P., Figueiredo, P., Xavier, M. A., Anjos, I. D., Dinardo-Miranda, L. L., Scarpari, M. S., Garcia, J. C., Bidóia, M. A. P., Silva, D. D. Mendonça, J. D., Kantack, R. A. D., Campos, M. F., Brancaliao, S. R., Petri, R. H. and Miguel, P. E. M. (2012). Documentos IAC, 109: Sistema de multiplicação de cana-de-açúcar com uso de mudas pré-brotadas (MPB), oriundas de gemas individualizadas. Ribeirão Preto: Instituto Agronômico de Campinas.

Libardi, L. G. P., Faria, R. T., Dalri, A. B., Rolim, G. S., Palaretti, L. F., Coelho, A. P. and Martins, I. P. (2019). Evapotranspiration and crop coefficient (Kc) of pre-sprouted sugarcane plantlets for greenhouse irrigation management. Agricultural Water Management, 212, 306316. https://doi.org/10.1016/j.agwat.2018.09.003

Machado, R. S., Ribeiro, R. V., Marchiori, P. E. R., Machado, D. F. S. P., Machado, E. C. and Landell, M. G. A. (2009). Respostas biométricas e fisiológicas ao déficit hídrico em cana-de-açúcar em diferentes fases fenológicas. Pesquisa Agropecuária Brasileira, 44, $1575-1582$. https://doi.org/10.1590/S0100-204X2009001200003

Marchiori, P. E. R., Machado, E. C., Sales, C. R. G., Espinoza-Núñez, E., Magalhães Filho, J. R., Souza, G. M., Pires, R. C. M. and Ribeiro, R. V. (2017). Physiological plasticity is important for maintaining sugarcane growth under water deficit. Frontiers in Plant Science, 8 , 1-12. https://doi.org/10.3389/fpls.2017.02148

Moreira, D. R. and Cardoso, V. J. M. (1998). Effect of soil moisture content and the irrigation frequency on the sugarcane germination. Pesquisa Agropecuária Brasileira, 33, 721-729. 
Ometto, J. C. (1981). Bioclimatologia Vegetal. São Paulo: Agronômica Ceres.

R Core Team (2018). R: A language and environment for statistical computing. R Foundation for Statistical Computing, Vienna, Austria. [Accessed Mar. 22, 2020]. Available at: https://www.R-project.org/.

Ribeiro, R. V., Machado, R. S., Machado, E. C., Machado, D. F. S. P., Magalhães Filho, J. R. and Landell, M. G. A. (2013). Revealing droughtresistance and productive patterns in sugarcane genotypes by evaluating both physiological responses and stalk yield. Experimental Agriculture, 49, 212-224. https://doi.org/10.1017/S0014479712001263

Silveira, N. M., Marcos, F. C. C., Frungillo, L., Moura, B. B., Seabra, A. B., Salgado, I., Machado, E. C., Hancock, J. T. and Ribeiro, R. V. (2017). S-nitrosoglutathione spraying improves stomatal conductance, Rubisco activity and antioxidant defense in both leaves and roots of sugarcane plants under water deficit. Physiologia Plantarum, 160, 383-395. https://doi.org/10.1111/ppl.12575

Van den Driessche, R. (1991). Influence of container nursery regimes on drought resistance of seedlings following planting. I. Survival and growth. Canadian Journal of Forest Research, 21, 555-565. https://doi.org/10.1139/x91-077

Yang, S. J. and Chen, J. B. (1980). Germination response of sugarcane cultivars to soil moisture and temperature. In Seventeenth Congress of the International Society of Sugar Cane Technologists. [Accessed Feb. 4, 2020]. Available at: https://www.cabdirect.org/cabdirect/ abstract/19831978854

Zorzeto, T. Q., Dechen, S. C. F., Abreu, M. F. and Fernandes Júnior, F. (2014). Caracterização física de substratos para plantas. Bragantia, 73, 300-311. https://doi.org/10.1590/1678-4499.0086 